\title{
Diagnosis dan penanganan rehabilitasi medik pada anak dengan Attention Deficit Hyperactivity Disorder
}

\author{
Bayu D. Susanto \\ Lidwina S. Sengkey
Program Studi Ilmu Kedokteran Fisik dan Rehabilitasi Fakultas Kedokteran
Universitas Sam Ratulangi - RSUP Prof. Dr. R. D. Kandou Manado \\ Email: bayumenado@gmail.com
}

\begin{abstract}
Attention deficit hyperactivity disorder (ADHD) is one of the most common childhood disorders and can continue through adolescence and adulthood. The average age of onset is 7 years old. Symptoms in children is characteriterized by inattention, hyperactivity and impulsivity, or a combination of these symptoms, which compromise basic daily functions such as learning to read and making friends. ADHD is a complex disorder of impairment of brain functions, associated with low rates of high-school graduation and completion of postsecondary education as well as poor peer relationships, even when it is appropriately managed, leading to high economic and social burdens. In many cases, it is accompanied by one or more serious psychiatric comorbidities. In practice, the diagnosis is often made in children who meet some but not all of the criteria recommended in DSM-IV. According to National Institute of Mental Health and professional organizations such as AACAP, the management of children with ADHD is a comprehensive, multidisciplinary and multimodal approach. The managerial team of children with ADHD involves medical rehabilitation specialists, physiatrists with occupational therapiests, psychologists, social workers, parents, teachers, care givers, and environment.
\end{abstract}

Keywords: ADHD, inattention, hyperactivity, impulsivity, rehabilitation medicine

\begin{abstract}
Abstrak: Attention deficit hyperactivity disorder (ADHD) adalah adanya pola menetap dari inatensi yang disertai hiperaktifitas dan impulsivitas, umumnya terjadi pada anak usia dini dan usia sekolah. Gejala dapat diketahui sebelum usia 7 tahun dan dapat menetap sampai masa remaja dan dewasa. ADHD dapat mengganggu fungsi dasar seorang anak, permasalahan dalam hal belajar, dan kesulitan membina hubungan dengan teman. ADHD merupakan gangguan yang kompleks dari fungsi otak yang menimbulkan masalah dalam pendidikan dan sosial serta membutuhkan biaya yang cukup besar. Pada banyak kasus disertai oleh 1 atau lebih masalah psikiatri yang serius. Kriteria diagnosis didasarkan pada Diagnostic and Statistic Manual IV (DSM-IV). Sampai saat ini belum ada satu jenis terapi yang dapat diakui untuk menyembuhkan anak dengan ADHD secara total. Berdasarkan National Institute of Mental Health serta organisasi profesi lainnya di dunia seperti AACAP penanganan anak dengan ADHD ialah dengan pendekatan komprehensif yang multidisiplin dan multimodal. Penanganan pada anak dengan ADHD melibatkan multidisipliner ilmu termasuk dokter spesialis kedokteran fisik dan rehabilitasi bersama tim termasuk psikolog, okupasi terapi, sosial medik, orang tua, guru, care giver dan lingkungan.
\end{abstract}

Kata kunci: ADHD, inattention, hyperactivity, impulsivity, rehabilitation medicine

Attention deficit hyperactivity disorder (ADHD) merupakan salah satu kelainan perkembangan terbanyak pada masa anak dan dapat berlangsung sampai masa remaja dan dewasa. Pada ADHD terjadi gangguan perkembangan neural yang bersifat 
kompleks ${ }^{1}$ dengan gangguan pemusatan perhatian disertai hiperaktif. Kenyataannya, ADHD tidak selalu disertai dengan gangguan hiperaktif. Oleh karena itu, makna istilah ADHD di Indonesia, lazimnya diterjemahkan menjadi Gangguan Pemusatan Perhatian dengan/tanpa Hiperaktif $(\mathrm{GPP} / \mathrm{H}) .^{1-4}$ ADHD memiliki suatu pola yang menetap dari kurangnya perhatian dan atau hiperaktivitas, yang lebih sering dan lebih berat bila dibandingkan dengan anak lain pada taraf perkembangan yang sama. Biasanya didapatkan ciri-ciri ADHD ini pada dua atau lebih situasi yang berbeda seperti di rumah, di sekolah, dan di tempat kerja. ${ }^{1-3}$ Anak dengan ADHD selalu memiliki tiga komponen ciri utama yang sama yaitu inattention, impulsivity, dan hyperactivity. ${ }^{4}$

Penyebab pasti ADHD yang tampak berlaku bagi semua gangguan belum diketahui dan diduga penyebabnya ialah disfungsi frontolimbik. Berbagai virus, zatzat kimia berbahaya yang banyak dijumpai di lingkungan sekitar, faktor genetika, masalah selama kehamilan atau kelahiran, atau apa saja yang dapat menimbulkan kerusakan perkembangan otak, berperan penting sebagai faktor penyebab ADHD ini. Televisi, komputer, dan video game mungkin mempunyai andil dalam memunculkan atau memperberat gejala ini., ${ }^{3,9}$

Diagnosis anak dengan ADHD tidak mudah; kadang-kadang terdapat dua faktor normal yang salah didiagnosis. Tidak ada satu tes untuk mendiagnosis anak secara pasti mengingat gejala bervariasi, tergantung usia dan lingkungan. Identifikasi dengan DSM IV memerlukan informasi dari keluarga orang tua, guru, pengasuh dan pemeriksaan dokter anak psikologi pertama kali dan dokter psikiatris. ${ }^{9,10}$

Evaluasi yang penting sebelum dilakukan penanganan mencakup neurological level, psychological level, behavioural level, environment, task performance, family dynamic, dan support. ${ }^{4}$

Penanganan pada anak ADHD difokuskan untuk mengurangi gejala-gejala ADHD dan memperbaiki fungsi. Penanganan dalam bidang rehabilitasi medik berupa terapi relaksasi, terapi perilaku kognitif, sensori integrasi, terapi snoezellen, serta terapi musik dan sosial medik. Diperlukan penanganan medikasi yang umum digunakan yaitu obat stimulan dan non stimulan, dan obat untuk memperbaiki fungsi fisik. Pengobatan dengan psikoterapi termasuk terapi perilaku. Sangat diperlukan kerjasama orang tua, guru, dan caregiver dalam keberhasilan penanganan anak dengan ADHD. ${ }^{1}$

\section{Epidemiologi}

ADHD merupakan gangguan neurobehavioral pada anak yang terbanyak, mencakup sekitar 50\% yang dirujuk ke neurologis anak, neuropsikologis, behavioral pediatrician, dan psikiatri anak. $^{5}$ Prevalensi gangguan ini sebesar 2,2\% untuk tipe hiperaktif-impulsif, 5,3\% untuk tipe campuran hiperaktif-impulsif dan inatensi, serta 15,3\% untuk ADHD tipe inatensi. ADHD terjadi pada $3-5 \%$ populasi anak dan didiagnosis 2-16\% pada anak usia sekolah. ${ }^{6}$ Terdapat kecende-rungan ADHD lebih sering terjadi pada anak laki-laki dibandingkan anak perempuan dengan perbandingan $3: 1$. $^{3,7}$

\section{Etiopatofisiologi}

Penyebab ADHD dipahami sebagai disregulasi neurotransmiter tertentu di dalam otak yang membuat seseorang lebih sulit untuk memiliki atau mengatur stimulus internal dan eksternal. Beberapa neurotransmiter, termasuk dopamin dan norepinefrin, memengaruhi produksi, pemakaian, pengaturan neuro-transmiter lain serta beberapa struktur otak.,

Faktor-faktor yang mungkin berperan dalam terjadinya ADHD, yaitu:

1. Faktor genetik: Mutasi gen pengkode neurotransmiter dan reseptor dopamin (D2 dan D4) pada kromosom 11p memegang peranan terjadinya ADHD, dalam hal ini reseptor D2 dan D4. ${ }^{11-13}$

2. Cedera otak: Telah lama diperkirakan bahwa anak yang terkena ADHD mendapat cedera otak yang minimal dan samar-samar pada sistem saraf pusatnya 
selama periode janin dan perinatalnya. ${ }^{6,9}$

3. Faktor neurokimiawi: Banyak neurotransmiter telah dihubungkan dengan gejala defisit-atensi dan hiperaktivitas. Sebagian temuan berasal dari pemakaian banyak medikasi yang menimbulkan efek positif pada gangguan. Obat yang paling banyak diteliti dalam terapi gangguan defisit-atensi/hiperaktivitas ialah stimulan yang memengaruhi dopamin maupun norepinefrin. Stimulan meningkatkan katekolamin dengan mempermudah pelepasannya dan menghambat ambilannya. Stimulan dan beberapa obat trisiklik, sebagai contoh, desipramine (Norpramine) menurunkan 3-methoxy-4-hidroxyphenilglycol urin (MHPG) yang merupakan metabolit dari norepinefrin. Clonidine (Catapres), suatu agonis norepinefrin, berguna dalam mengobati hiperaktivitas. Obat lain yang menurunkan hiperaktivitas ialah obat trisiklik dan dan inhibitor monoamin oksidase (MAOI). ${ }^{10}$

4. Struktur anatomi: Pemeriksaan brain imaging yang dilakukan pada anak dengan ADHD menunjukkan pengecilan volume otak yang bermakna pada korteks prefrontal dorsolateral, kaudatus, palidum, korpus kalosum, dan serebelum. $^{12}$ Rapport et al. dari National Institute of Mental Health meneliti anak dengan ADHD menggunakan Magnetic Resonance Imaging (MRI), menyatakan adanya pengecilan lobus prefrontal kanan, nukleus kaudatus kanan, globus palidus kanan, serta vermis dibandingkan dengan anak tanpa ADHD. ${ }^{10}$

5. Faktor psikososial: Anak-anak dalam institusi seringkali hiperaktif dan memiliki rentan atensi rendah. Tanda tersebut terjadi akibat adanya pemutusan hubungan emosional yang lama, dan gejala menghilang jika faktor pemutus dihilangkan, seperti melalui adopsi atau penempatan di rumah penitipan. ${ }^{10}$

\section{Klasifikasi dan gejala klinik}

Seperti telah dikemukakan sebelumnya bahwa tidak mudah untuk membedakan penyandang ADHD terutama yang tergolong ringan dengan anak normal yang sedikit lebih aktif dibanding anak yang lainnya. Tidak ada tes untuk mendiagnosis secara pasti jenis gangguan ini, mengingat gejalanya bervariasi tergantung pada usia, situasi, dan lingkungan. ${ }^{4}$ Hal ini menunjukkan ADHD merupakan suatu gangguan yang kompleks berkaitan dengan pengendalian diri dalam berbagai variasi gangguan tingkah laku.

Ciri-ciri ADHD muncul pada masa kanak-kanak awal, bersifat menahun, dan tidak diakibatkan oleh kelainan fisik yang lain, mental, maupun emosional. Ciri utama individu dengan gangguan pemusatan perhatian meliputi: gangguan pemusatan perhatian (inattention), gangguan pengendalian diri (impulsivity), dan gangguan dengan aktivitas yang berlebihan (hiperactivity). Terdapat 3 subtipe ADHD, yaitu: $:^{9,14}$

1. Predominan hiperaktif-impulsif (ADHD/ HI): Simtom terbanyak $(\geq 6)$ ialah kategori hiperaktif-impulsif; $<6$ simtom inatensi.

2. Predominan inatensi: Simtom terbanyak ( $\geq 6)$ ialah kategori inatensi dan $<6$ simptom dari hiperaktif-impulsif. Anak dengan subtipe ini kurang berperan atau mempunyai kesulitan bersama dengan anak lain. Mereka duduk tenang, tetapi tidak memberikan perhatian kepada apa yang dilakukan. Orang tua mungkin tidak memperhatikan simtom ADHD

3. Kombinasi hiperaktif-impulsif dan inatensi: $\geq 6$ simtom inatensi dan $\geq 6$ simtom hiperaktif-impulsif.

Kebanyakan anak dengan ADHD mempunyai tipe kombinasi.

\section{Diagnosis}

Kriteria diagnostik ADHD berdasarkan DSM-IV ialah satu dari kriteria (1) atau (2) berikut: ${ }^{9}$

1. Gangguan pemusatan perhatian (inatensi): $\geq 6$ gejala inatensi berikut telah menetap selama sekurangkurangnya 6 bulan bahkan sampai tingkat yang maladaptif dan tidak 
konsisten dengan tingkat perkembangan.

a. Sering gagal dalam memberikan perhatian pada hal yang detil dan tidak teliti dalam mengerjakan tugas sekolah, pekerjaan atau aktivitas lainnya.

b. Sering mengalami kesulitan dalam mempertahankan perhatian terhadap tugas atau aktivitas bermain.

c. Sering tampak tidak mendengarkan apabila berbicara langsung.

d. Sering tidak mengikuti instruksi dan gagal menyelesaikan tugas sekolah, pekerjaan sehari-hari, atau tugas di tempat kerja (bukan karena perilaku menentang atau tidak dapat mengikuti instruksi).

e. Sering mengalami kesulitan dalam menyusun tugas dan aktivitas.

f. Sering menghindari, membenci atau enggan untuk terlibat dalam tugas yang memiliki usaha mental yang lama (seperti tugas di sekolah dan pekerjaan rumah).

g. Sering menghilangkan atau ketinggalan hal-hal yang perlu untuk tugas atau aktivitas (misalnya tugas sekolah, pensil, buku ataupun peralatan)

h. Sering mudah dialihkan perhatiannya oleh stimulasi dari luar.

i. Sering lupa dalam aktivitas seharihari.

2. Hiperaktivitas-impulsivitas: $\geq 6$ gejala hiperaktivitas-impulsivitas berikut ini telah menetap selama sekurangkurangnya enam bulan sampai tingkat yang maladaptif dan tidak konsisten dengan tingkat perkembangan.

Gejala hiperaktivitas ialah sebagai berikut:

a. Sering gelisah dengan tangan dan kaki atau sering menggeliat-geliat di tempat duduk.

b. Sering meninggalkan tempat duduk di kelas atau di dalam situasi yang diharapkan anak tetap duduk.

c. Sering berlari-lari atau memanjat secara berlebihan dalam situasi yang tidak seharusnya.

d. Sering mengalami kesulitan bermain atau terlibat dalam aktivitas waktu luang secara tenang.

e. Sering dalam keadaan "siap bergerak/ pergi" (atau bertindak seperti digerakkan oleh mesin).

f. Sering bicara berlebihan.

Gejala impulsivitas ialah sebagai berikut:

g. Tidak sabar, sering menjawab pertanyaan tanpa berpikir lebih dahulu sebelum pertanyaan selesai.

h. Sering sulit menunggu giliran.

i. Sering menyela atau mengganggu orang lain sehingga menyebabkan hambatan dalam lingkungan sosial, pendidikan, dan pekerjaan.

Beberapa gejala hiperaktif-impulsif atau inatentif yang menyebabkan gangguan telah ada sebelum usia 7 tahun. Beberapa gangguan akibat gejala ada selama dua atau lebih situasi. Harus terdapat bukti jelas adanya gangguan yang bermakna secara klinis dalam fungsi sosial, akademik, atau fungsi pekerjaan. Gejala tidak semata-mata selama perjalanan gangguan perkembangan pervasif, skizofrenia, atau gangguan psikotik lain, dan tidak diterangkan lebih baik oleh gangguan mental lain. ${ }^{9}$

Kode berdasarkan tipe ialah sebagai berikut: $^{9}$

- 314.01 ADHD tipe kombinasi: jika kriteria A1 dan A2 ditemukan selama 6 bulan yang lalu.

- 314.00 ADHD predominan tipe inatensi: jika kriteria A1 ditemukan tetapi kriteria A2 tidak ditemukan selama 6 bulan yang lalu.

- 314.01 ADHD predominan tipe hiperaktif-impulsif: jika kriteria A2 ditemukan tetapi kriteria A1 tidak ditemukan selama 6 bulan yang lalu.

Kriteria diagnosis ADHD menurut DSM IV dan DSM IV-TR ini telah mengalami revisi melalui DSM V. Daftar gejala pada DSM V tidak berbeda dengan DSM IV dan IV-TR. Perbedaan yang tampak ialah pada DSM V setelah dituliskan gejala akan diberikan beberapa contoh yang dapat muncul pada penderita ADHD, termasuk contoh gejala yang timbul pada masa remaja dan dewasa. 
Selain itu perbedaan ditunjukkan pada onset timbulnya gejala ADHD yang dimulai pada usia 12 tahun. $^{9}$

\section{Diagnosis banding ${ }^{10,15}$}

Dalam praktik sehari-hari, ADHD sering kali memiliki gejala yang tumpang tindih dengan autism spectrum disorder (ASD) dan communication disorder speech delayed. Pada penderita speech delayed harus dipastikan ada tidaknya gangguan pendengaran, retardasi mental atau kurang stimulasi. Persamaan ADHD dengan ASD ialah adanya gangguan konsentrasi, tak mampu menunggu giliran, meminta sesuatu dengan cara non-verbal, kurang peduli dengan lingkungan dan bila marah sulit ditenangkan. ${ }^{12}$

\section{Penatalaksanaan}

ADHD merupakan gangguan yang bersifat heterogen dengan manifestasi klinis beragam. Sampai saat ini belum ada satu jenis terapi yang dapat diakui untuk menyembuhkan anak dengan ADHD secara total. Berdasarkan National Institute of Mental Health, serta organisasi profesi lainnya di dunia seperti American Academy of Child and Adolescent Psychiatry (AACAP), penanganan anak dengan ADHD dilakukan dengan pendekatan komprehensif berdasarkan prinsip pendekatan yang multidisiplin dan multimodal. ${ }^{6}$

Tujuan utama penanganan anak dengan ADHD ialah: ${ }^{6}$

- Memperbaiki pola perilaku dan sikap anak dalam menjalankan fungsinya sehari-hari terutama dengan memperbaiki fungsi pengendalian diri.

- Memperbaiki pola adaptasi dan penyesuaian sosial anak sehingga terbentuk kemampuan adaptasi yang lebih baik dan matang sesuai dengan tingkat perkembangan anak.

Berdasarkan prinsip pendekatan yang multidisiplin dan multimodal ini maka terapi yang diberikan dapat berupa obat, ${ }^{6,14}$ diet, ${ }^{14}$ latihan, ${ }^{14}$ terapi perilaku, terapi kognitif dan latihan keterampilan sosial; juga psikoedukasi kepada orang tua, pengasuh serta guru yang sehari-hari berhadapan dengan anak tersebut. ${ }^{6}$

1. Medikamentosis: Cara ini dapat mengontrol ADHD sampai 70-80\%. Obat yang merupakan pilihan pertama ialah obat golongan psikostimulan. Meskipun disebut stimulan, pada dasarnya obat ini memiliki efek yang menenangkan pada penderita ADHD. ${ }^{4,5}$ Yang termasuk stimulan antara lain: amphetamine, dextroamphetamine dan derivatnya. Pemberian obat psikostimulan dikatakan cukup efektif mengurangi gejala-gejala ADHD. ${ }^{6}$ Obat ini memengaruhi sistem dopaminergik atau sirkuit noradrenergik korteks lobus frontalis-subkortikal, meningkatkan kontrol inhibisi dan memperlambat potensiasi antara stimulasi dan respon, sehingga mengurangi gejala impulsif dan tidak dapat menyelesaikan tugas. ${ }^{5}$ Efek sampingnya ialah penarikan diri dari lingkungan sosial, fokus yang berlebih, iritabel, sakit kepala, cemas, sulit tidur, hilang nafsu makan, sindrom Tourette, serta munculnya tic. ${ }^{6,7}$

2. Diet: Meta-analisis menemukan bahwa menghindari pewarna makanan buatan dan bahan pengawet sintetik secara statistik bermanfaat mencegah terjadinya gejala ADHD. ${ }^{15}$ Keseimbangan diet karbohidrat dan asam amino (triptophan sebagai serotonin substrate) juga dapat menjadi upaya lain. ${ }^{15}$ Belum ada bukti bahwa pemanis buatan seperti aspartam memperburuk ADHD. ${ }^{15}$

3. Rehabilitasi medik: Mengembangkan kemampuan fungsio-nal dan psikologis seorang individu dan mekanismenya sehingga dapat mencapai kemandirian dan menjalani hidup secara aktif.

\section{Penanganan rehabilitasi medik pada anak dengan ADHD}

\section{Terapi okupasi}

Terapi okupasi terdiri dari terapi relaksasi, terapi perilaku kognitif (cognitive behavior therapy), terapi sensori integrasi, terapi snoezellen, dan terapi musik. ${ }^{16}$ 
Terapi relaksasi adalah terapi yang menggunakan kekuatan pikiran dan tubuh untuk mencapai suatu perasaan rileks. Terapi relaksasi bertujuan untuk dapat mengontrol ansietas, stres, ketakutan dan ketegangan, memperbaiki konsentrasi, meningkatkan kontrol diri, meningkatkan harga diri dan kepercayaan diri, serta meningkatkan kreativitas. ${ }^{18}$

Terapi perilaku kognitif bertujuan untuk mengubah perilaku seseorang dengan mengubah pemikiran dan persepsi terutama pola berpikirnya. Terapi perilaku berfokus untuk mengurangi respon kebiasaan (seperti marah, takut, dan sebagainya) dengan cara mengenal situasi atau stimulus. Terapi ini melatih kemampuan berpikir, menggunakan pendapat dan membuat keputusan, dengan fokus memperbaiki defisit memori, konsentrasi dan atensi, persepsi, proses belajar, membuat rencana, serta pertimbangan. Pada anak-anak, terapi ini memerlukan dukungan penuh dari orang tua atau anggota keluarga lain. Intervensi pada terapi ini juga harus menarik seperti menggunakan media gambar kartun, role play, menggunakan bahasa menarik sesuai usianya, media latihan yang menyenangkan dan penuh warna. Bentuk lain dari intervensi ini dapat juga berupa metode self recording. ${ }^{19}$

Terapi sensori integrasi bertujuan untuk meningkatkan kemampuan proses sensoris dengan cara:

- Mengembangkan modulasi sensoris yang berhubungan dengan atensi dan kontrol perilaku

- Mengintegrasikan informasi sensoris untuk membentuk skema persepsi baik sebagai dasar ketrampilan akademis, interaksi sosial dan kemandirian fungsional.

- Fokus terapi diarahkan untuk memunculkan motivasi intrinsik anak untuk bermain interaktif dan bermakna.

Terapi sensori integrasi memberikan stimulasi sensori dan interaksi fisik untuk dapat meningkatkan integrasi sensori dan peningkatan kemampuan belajar dan perilaku. Terapi ini merupakan terapi modalitas yang kompleks dan memerlukan partisipasi aktif pasien dan bersifat individual melalui aktivitas yang bertujuan melibatkan stimulasi sensorik untuk perbaikan organisasi dan proses neurologis.

Terapi snoezellen ${ }^{20,22}$ dilakukan untuk memengaruhi sistem saraf pusat melalui pemberian rangsangan yang cukup pada sistem sensori primer (penglihatan, pendengaran, peraba, perasa lidah, penciuman) dan juga pada sistem sensori internal (vestibular dan proprioseptif). Dalam bahasa Belanda kata snoezellen merupakan gabungan dari 2 kata, yaitu: "snufflen" yang berarti eksplorasi aktif dan "doezelen" yang berarti relaksasi atau pasif. Tujuan terapi snoezellen pada anak ADHD ialah:

- Anak mampu konsentrasi dan atensi terhadap satu stimulus

- Anak mampu rileks secara psikis sehingga mengurangi perilaku impulsif

- Anak mampu memberikan reaksi yang tepat terhadap lingkungan

- Anak mampu melakukan kontak dengan orang lain

- Anak punya rasa percaya diri

- Anak mampu mengeksplorasi lingkungan

- Anak mampu rileks secara fisik yang ditandai dengan penurunan muscle tension

Ruangan snoezellen khusus dirancang untuk memberi stimulasi pada berbagai sensasi, menggunakan efek lampu/cahaya, warna, musik, wangi-wangian dan sebagainya. Kombinasi dari bahan berbeda pada dinding dieksplorasi menggunakan sensasi taktil, dan pada lantai disesuaikan untuk merangsang sensasi keseimbangan. Idealnya, snoezellen merupakan terapi yang tidak diarahkan dan dapat bertahap memberikan pengalaman multi sensorik atau fokus pada 1 sensorik saja, secara sederhana melalui adaptasi terhadap lampu/cahaya, atmosfer, suara, dan tekstur kepada kebutuhan spesifik pasien. Lingkungan snoezellen memberikan stimulasi langsung dan tidak langsung dari modalitas sensorik dan dapat digunakan secara individu atau berkelompok untuk memberikan pendekatan sensorik. 
Peralatannya disesuaikan dengan tiap-tiap anak ADHD: $:^{20,22}$

- Stimulasi visual: serat optik semprot, proyektor dengan gambar.

- Stimulasi pendengaran (suara): kaset relaksasi, getaran suara dari peralatan musik.

- Olfaktori (bau): aroma terapi dapat mengurangi tingkat kecemasan.

- Gustatori (rasa): setiap zat makanan menyediakan rasa yang berbeda atau tekstur.

- Stimulasi taktil (sentuhan): bantal dan kasur dengan vibrasi, kain bertekstur.

- Rangsangan proprioseptif dan vestibular (gerakan): kursi goyang, rocking horses.

Terdapat beberapa macam ruang snoezellen yang ditata dengan tujuan yang berbeda contohnya: $:^{20,22}$

- Ruang relaksasi: Ruang ini dipenuhi dengan warna yang lembut dan tidak mencolok, lagu-lagu lembut atau musik relaksasi, pemberian aroma ruangan dengan aroma yang lembut, .ampu penerangan yang lembut

- Ruang aktivitas/adventure: Ruangan ini dipenuhi dengan warna-warna yang mencolok, stimulasi visual yang dinamis, musik yang dinamis, dan alatalat permainan aktif

- Ruang natural: Ruangan alami seperti kebun bunga/taman, kolam ikan/ akuarium, terdapat pasir, tanah, dan air

Terapi musik merupakan terapi efektif dan alat edukasi untuk anak dengan ADHD sehingga dapat mempengaruhi perubahan keterampilan yang penting pada gangguan belajar atau perilaku. Terapi musik mencakup beberapa hal, yaitu: ${ }^{23}$

- Keterampilan kognitif: Musik dapat menstimulasi dan memfokuskan atensi dan terutama untuk orang yang tidak respon dengan intervensi lain. Seluruh intervensi terapeutik akan terstruktur dengan musik, untuk mempertahankan atensi.

- Keterampilan fisik: Terdapat bukti ilmiah yang menunjukkan bahwa ritme teratur dapat menstimulasi dan mengorganisasikan respon otot untuk menimbulkan rasa rileks.

- Keterampilan komunikasi: Efektif untuk menstimulasi dan memotivasi bicara, serta memberi ruang untuk komunikasi non-verbal.

- Keterampilan sosial: Memberi kesempatan untuk orang dengan disabilitas perkembangan untuk berinteraksi dan bekerja sama dengan orang lain.

- Keterampilan emosional: Musik memberi kesempatan untuk mengekspresikan dan merasakan berbagai emosi. Keinginan untuk berpartisipasi pada musik dapat membantu untuk mengontrol emosi yang meledak-ledak, mengubah mood, serta dapat mencapai efek positif dari harga diri.

\section{Terapi psikologi $i^{13,15,16}$}

Psikoterapi yang diberikan pada penderita ADHD termasuk dalam pelatihan kepada orang tua untuk memperbaiki lingkungan di sekitar rumah dan sekolah. Terdapat berbagai pendekatan psikoterapi yang dapat dilakukan oleh seorang psikolog; penggunaannya tergantung kepada pasien dan simptomnya yang meliputi support groups, parent training, dan social skills training.

Memperbaiki lingkungan di sekitar rumah dan sekolah dapat memperbaiki perilaku anak dengan ADHD, namun kendalanya ialah orang tua dari anak ADHD memperlihatkan kekurangan yang sama terhadap diri mereka sendiri, sehingga mereka tidak dapat cukup membantu anaknya dengan kesulitannya. Intervensi pendidikan yang berbeda untuk orang tua disebut sebagai parent management training. Teknik ini meliputi operant conditioning yaitu sebuah aplikasi rewards untuk suatu perilaku yang baik dan hukuman untuk perilaku yang buruk.

Manajemen di dalam kelas (edukasi kepada guru) dilakukan sama dengan parent management training yaitu guru diajari tentang ADHD dan teknik untuk memperbaiki perilaku yang diaplikasikan 
di ruangan kelas. Strategi yang digunakan meliputi peningkatan penyusunan aktivitas di kelas atau daily feedback.

\section{Terapi sosial medik}

Penanganan ADHD dalam peran sosial medik difokuskan pada bantuan perorangan dan keluarga yang kesulitan dalam penyesuaian diri dan pelaksanaan fungsifungsi sosial diakibatkan oleh kondisikondisi yang disfungsi. Terapi ini berkaitan dengan usaha untuk menjangkau dan memanfaatkan sumber dalam pemecahan masalah social dengan tujuan pelayanan untuk sosialisasi dan pengembangan, penyembuhan, pemberian bantuan, rehabilitasi dan perlindungan sosial, serta pemberian informasi dan nasehat. $^{24}$

\section{Terapi perilaku}

Strategi spesifik yang dapat dilakukan untuk terapi perilaku ini ialah: ${ }^{7}$

- Reward system (anak diberikan 'hadiah' bila dapat menyelesaikan tugas atau berperilaku baik).

- Time out (misal: anak yang memukul adiknya dihukum duduk di pojok ruangan selama 5 menit).

- Response cost (misal: anak dilarang nonton TV bila tidak menyelesaikan PR).

- Token economy (anak mendapatkan 'bintang' bila menyelesaikan tugas dan kehilangan 'bintang' bila berjalan-jalan di kelas. Jumlah bintang menentukan reward yang diterima).

Penting pula ditekankan bahwa dukungan orang tua sangat menentukan suksesnya terapi sehingga terapi perilaku ini disertai dengan edukasi dan pelatihan pasien serta keluarganya.

\section{Modifikasi lingkungan}

Anak-anak dengan ADHD tidak beradaptasi dengan baik untuk mengubah dan tidak berfungsi dengan baik dalam lingkungan yang sangat memberikan banyak stimulasi. Di sekolah, mereka harus ditempatkan di barisan depan sehingga mereka dapat lebih memperhatikan guru.
Seringkali, anak dengan ADHD mendapatkan keuntungan lebih dari metode mengajar satu-satu atau pengajaran dalam kelompok kecil. Rutinitas kelas harus diprediksi dan hanya satu tugas yang diberikan kepada anak pada suatu waktu. ${ }^{17,18,25}$ Rutinitas di rumah juga harus terstruktur dengan baik dan teratur. Keluarga harus menghindari keramaian, supermarket, dan pusat perbelanjaan besar yang dapat memberikan terlalu banyak stimulasi bagi anak. Kelelahan juga harus dihindari ketika anak menjadi tak terkontrol dan hiperaktivitas meningkat ketika anak menjadi lelah. ${ }^{16,17}$ Saran dari psikiater, dokter anak dan social worker diperlukan dalam kasus-kasus individual karena mungkin ada kebutuhan untuk penempatan sekolah khusus atau program khusus untuk modifikasi perilaku. Anak yang cerdas juga dapat ditempatkan dalam program sekolah normal. Obat jarang diindikasikan kecuali terdapt indikasi tertentu seperti hiperaktif atau ketidakstabilan suasana hati. ${ }^{17,18,25}$

\section{Prognosis $^{17}$}

Perjalanan anak dengan ADHD bervariasi; ada yang mengalami remisi, tetapi ada juga yang menetap.

1. Persisten atau menetap: Pada 40-50\% kasus, gejala akan persisten hingga masa remaja atau dewasa. ${ }^{9,10}$ Gejala akan lebih cenderung menetap jika terdapat riwayat keluarga, peristiwa negatif dalam hidupnya, komorbiditas dengan gejala-gejala perilaku, depresi dan gangguan cemas. Pada beberapa kasus, hiperaktivitas akan menghilang, tetapi tetap mengalami inatensi dan kesulitan mengontrol impuls (tidak hiperaktif, tetapi impulsif dan ceroboh). Anak ini rentan dengan penyalahgunaan alkohol dan narkoba, kegagalan di sekolah, sulit mempertahankan pekerjaan, serta cenderung melakukan pelanggaran hukum.

2. Remisi: Pada 50\% kasus, gejalanya akan meringan atau menghilang pada masa remaja atau dewasa muda. Biasanya remisi terjadi antara usia 12 hingga 20 
tahun. Gejala yang pertama kali memudar ialah hiperaktivitas dan yang paling terakhir ialah distractibility.

a. Remisi total: Anak yang mengalami remisi total akan memiliki masa remaja dan dewasa yang produktif, hubungan interpersonal yang memuaskan, dan memiliki gejala sisa yang sedikit.

b. Remisi parsial: Pada masa dewasanya, anak dengan remisi parsial mudah menjadi antisosial, mengalami gangguan mood, sulit mempertahankan pekerjaan, mengalami kegagalan disekolah, melanggar hukum, dan menyalahgunakan alkohol serta narkoba.

\section{Simpulan}

Attention deficit hyperactivity disorder (ADHD) adalah adanya pola menetap dari inatensi yang disertai hiperaktifitas dan impulsivitas, umumnya terjadi pada anak usia dini dan usia sekolah, dan dapat menetap sampai masa remaja dan dewasa. ADHD dapat mengganggu fungsi dasar seorang anak, permasalahan dalam hal belajar, dan kesulitan membina hubungan dengan teman.

Kriteria diagnosis didasarkan pada Diagnostic and Statistic Manual IV (DSMIV). Sampai saat ini belum ada satu jenis terapi yang dapat diakui untuk menyembuhkan anak dengan ADHD secara total.

Berdasarkan National Institute of Mental Health serta organisasi profesi lainnya di dunia seperti AACAP penanganan anak dengan ADHD ialah dengan pendekatan komprehensif yang multidisiplin dan multimodal.

\section{DAFTAR PUSTAKA}

1. New York State of Opportunity: Office of Mental Health, 2016: p. 1-10.

2. Carpenter R, Reddi B. Neurophysiology: A Conceptual Approach (5th ed). Florida: CRC Press, 2012; p. 77-274.

3. Wiguna T. Gangguan pemusatan perhatian dan hiperaktivitas $(\mathrm{GPPH})$. In: Elvira SD, Hadisukanto G, editors. Buku Ajar Psikiatri. Jakarta: Fakultas Kedokteran Universitas Indonesia, 2010; p. 441-54.
4. Sugiarmin M. Bahan ajar anak dengan attention defisit hyperactivity disorder. PBL, 2007; p. 1-5.

5. Shaywitz B, Fletcher J, Shaywitz S. Attention deficit hyperactivity disorder. In: Swiman K, Ashwal S, editors. Pediatric Neurology Principles and Practice (3rd ed). St Louis: Mosby, 1999; p. 585-94.

6. Wiguna T. Apakah anak dengan gangguan pemusatan perhatian/hiperaktivitas (GPPH) memerlukan obat? In: Pusponegoro $\mathrm{H}$, Widodo $\mathrm{D}$, Mngunadmaja I, penyunting. A Journey to Child Neurodevelopmental application in daily practice. Jakarta: IDAI Cabang Jakarta, 2010; p. 13746.

7. Bahtera T. Manajemen penderita gangguan perhatian dan hiperaktivitas. In: Purwanti A, Mexitalia, Wistiani, Mellyana O, penyunting. Symposium dan Workshop Early Detection on Neurodevelopmental Disorders. Semarang: Badan Penerbit UNDIP, 2007; p. 29-35.

8. Visser SN, Bitsko RH, Danielson ML, Ghandour RM, Blumberg SJ, Schieve LA, et al. Treatment of Attention Deficit/Hyperactivity Disorder among Children with Special Health Care Needs, J Pedriatr. 2015;166(6):1344-6.

9. American Psychiatric Association. Diagnostic and Statistical Manual of Mental Disorders (4th ed.). Washington, DC: American Psychiatric Publishing, 1994.

10. American Psychiatric Association. Diagnostic and Statistical Manual of Mental Disorders (5th ed.). Washington, DC: American Psychiatric Publishing, 2013; p. 59-65.

11. Roger WJ. Attention deficit hyperactivity disorder. In: Howlin $\mathrm{P}$, Udwin $\mathrm{O}$, editors. Outcomes in neurodevelopmental and genetic disorders. New York: Cambridge University Press, 2002.

12. Antshel KM, Macias MM, Barkley RA. The Child with Attention Deficit Hyperactivity Disorder. In: David RB, editor. Clinical Pediatric Neurology. New York; Demos Medical; 2009.

13. Wikipedia. Attention deficit hyperactivity 
disorder. Available from: http: //en.wikipedia.org/wiki/Attentiondeficit_hyperactivity_disorder_.2010.

14. Pediatric Attention Deficit Hyperactivity Disorder. Available from: http: //emedicine.medscape.com/article/91 2633-overview.

15. Mental help. ADHD Attention deficit hyperactivity disorder. Available from: http://www.mentalhelp. net/poc/view_doc.php?type $=$ doc\&id= $13871 \& \mathrm{cn}=3.2007$.

16. Chu S, Reynolds F. Occupational therapy for children with attention deficit hyperactivity disorder (ADHD), Part 1: a delineation model of practice. $\mathrm{Br}$ J Occup Ther. 2007;70(9):372-83.

17. Tamin TZ. Relaxation therapy. In: Workshop Relaxation Therapy. Manado: Perdosri, 2007.

18. Wiguna T. Gejala, latar belakang permasalahan dan kebutuhan anak dengan GPPH dan spektrum autistik. In: Buku Prosiding Simposium Sehari Kesehatan Jiwa. Jakarta. IDI, 2007; p. 68-71.

19. Hersen M, Gross AM. Handbook of Clinical Psychology, Children and
Adolescents. New Jersey: John Wiley and Son, 2008.

20. Perhimpunan Dokter Spesialis Kedokteran Fisik dan Rehabilitasi Indonesia. Layanan kedokteran fisik dan rehabilitasi. Jakarta: PB Perdosri, 2013; p. 186-90.

21. Waiman E, Soedjatmiko, Gunardi H, Sekartini R, Endyarni B. Sensori integrasi: dasar efektivitas dan terapi. Sari Pediatri. 2011;13:129-32.

22. Challenor YB, Borkow RB. Central nervous system plasticity and cognitive remediation. Boston: Butterworth Heinemann, 1996.

23. Coleman K, King B. Music therapy and developmental disabilities. Available from: http: //www.preludemusic therapy. com/dd.html. 1996.

24. Angliadi LS, Sengkey L, Gessal J, Mogi ThI. Ilmu Kedokteran Fisik dan Rehabilitasi, 2006; p. 33.

25. Swan K, Ho V, Tazkarji B, Auten B. Management of ADHD in PreschoolAged Children. Gainesville, Florida: University of Florida Health Science Center Libraries, 2013. 